\title{
PENGARUH PERTUMBUHAN PENDUDUK DAN PENGGUNAAN LAHAN TERHADAP KUALITAS AIR BERSIH
}

\author{
Muhammad Arwanda Agam Noeraga 1 , Galing Yudana 1, Paramita Rahayu 1 \\ ${ }_{1}$ Program Studi Perencanaan Wilayah dan Kota, Fakultas Teknik, Universitas Sebelas Maret
}

\begin{abstract}
Abstrak
Kecamatan Jatinangor Kabupaten Sumedang, ditetapkan sebagai Kawasan Strategis Provinsi (KSP) Jawa Barat dengan arahan prioritas pada bidang lingkungan hidup berdasarkan Rencana Tata Ruang Wilayah (RTRW) Provinsi Jawa Barat tahun 20092029. Selain itu, Jatinangor juga memiliki arahan prioritas pada bidang lingkungan dan sosial berdasarkan RTRW Kabupaten Sumedang tahun 2011-2031. Berdasarkan kedua arahan RTRW tersebut, keterkaitannya pada penelitian ini yaitu membahas urgensi permasalahan lingkungan hidup dan sosial kependudukan yang ada di Jatinangor. Jatinangor sendiri mengalami peningkatan pertumbuhan penduduk dan pertumbuhan guna lahan terbangun yang pesat, serta permasalahan lingkungan terkait air bersih yakni penurunan muka sumber air tanah dan penurunan debit sumber air Perusahaan Daerah Air Minum (PDAM). Pembahasan pada penelitian ini terkait dampak pertumbuhan penduduk dan guna lahan terhadap kualitas air bersih rumah tangga di Jatinangor. Di dalamnya terdapat komponen meliputi kepadatan penduduk; pertumbuhan guna lahan terbangun; perkembangan kondisi dan pengelolaan air bersih; serta kualitas air bersih rumah tangga berdasarkan persepsi masyarakat. Penelitian ini menggunakan data primer berupa observasi lapangan dan kuesioner; serta data sekunder. Teknik analisis yang digunakan adalah statistik deskriptif, skoring, dan spatial overlay. Kepadatan penduduk Jatinangor pada tahun 2016 lebih besar dari kepadatan penduduk tahun 2011, hal tersebut menunjukkan bahwa terjadinya peningkatan kepadatan penduduk. Sementara itu, penggunaan lahan terbangun dalam kurun waktu dua tahun mengalami peningkatan yang signifikan. Jatinangor mengalami penurunan kedudukan muka sumber air tanah, pencemaran sumber air tanah, penurunan debit sumber air PDAM, rendahnya jangkauan pelayanan air PDAM ke masyarakat, dan kurangnya partisipasi masyarakat dalam pengelolaan lingkungan air bersih. Lebih lanjut, persepsi masyarakat Jatinangor terkait kualitas air bersih rumah tangga menunjukkan bahwa kualitas air kurang memadai untuk kebutuhan rumah tangga sehari-hari. Berdasarkan perihal tersebut, pertumbuhan penduduk dan pembangunan fisik yang pesat sehingga konversi lahan sangat tinggi di Jatinangor berpengaruh terhadap kualitas air bersih rumah tangga.
\end{abstract}

Kata kunci: kualitas air bersih rumah tangga berdasarkan persepsi masyarakat; pengaruh; permasalahan lingkungan air bersih; pertumbuhan penduduk dan guna lahan terbangun

\begin{abstract}
Jatinangor Sub-district in Sumedang Regency, is designated as a Provincial Strategic Area (KSP) of West Java with environmental program as its prioritized aspect based on West Java Provincial Regional Masterplan (RTRW) 2009-2029. Similarly, Regional Masterplan (RTRW) of Sumedang Regency 2011-2031 states that Jatinangor prioritized programs are social and environmental aspect. Based on these two reference, the study aims at discussing the urgency of environmental and social problem in Jatinangor. Jatinangor has increased population growth and rapid land use change, as well as environmental issues related to clean water such as decreasing of the groundwater level and piped water debit of Local Government Enterprise for Water Supply (PDAM). Therefore the study particularly focuses on the effect of population growth and land use on household water quality in Jatinangor. The variables involved are population density; built up area; management of urban clean water supply; and household water quality based on community perceptions. This study uses primary and secondary data such as field observations and questionnaires; as well as statistical data. The analytical techniques are statistical descriptive, scoring, and spatial overlay. The results show that the population density of Jatinangor in 2016 was higher than the population density in 2011, indicating that there was an increase in population density. Meanwhile, the built up area has experienced a significant increase for the last two years. Jatinangor also experienced a decrease in the level of groundwater, pollution of groundwater, decrease in PDAM piped water debit, low water service coverage of PDAM, , and lack of community participation in clean water management. The perception of Jatinangor community to household clean water quality is inadequate for daily household needs. Therefore, it can be concluded that rapid population growth and rapid urban development trigger rapid land conversion that influences the quality of household water quality in Jatinangor
\end{abstract}

Keywords: clean water environment issues; effect; household water quality based on community perception; population growth and built land use 


\section{PENDAHULUAN}

Berdasarkan Peraturan Daerah (Perda) Provinsi Jawa Barat Nomor 22 Tahun 2010 tentang RTRW Jawa Barat tahun 2009-2029, Jatinangor ditetapkan menjadi Kawasan Strategis Provinsi (KSP) Jawa Barat dengan arahan prioritas pada bidang lingkungan hidup. Sementara itu, menurut Perda Kabupaten Sumedang Nomor 2 Tahun 2012 tentang RTRW Kabupaten Sumedang tahun 2011-2031, Jatinangor memiliki arahan prioritas pada bidang lingkungan dan sosial. Berdasarkan kedua arahan RTRW tersebut, keterkaitannya pada penelitian ini yaitu membahas urgensi permasalahan lingkungan hidup dan sosial kependudukan yang ada di Jatinangor. Jatinangor merupakan salah satu Kecamatan yang ada di Kabupaten Sumedang Jawa Barat dengan kepadatan penduduk tertinggi di Kabupaten Sumedang (BPS, 2016). Jatinangor mengalami pertumbuhan lahan terbangun yang pesat serta permasalahan lingkungan air bersih yakni penurunan muka sumber air tanah dan penurunan debit sumber air PDAM.

Menurut Kodoatie \& Sjarief (2010), pertumbuhan fisik perkotaan di dalamnya terdapat konflik kepentingan antara ruang terbangun dengan ruang terbuka hijau; antara tata ruang bangunan dengan tata ruang air; serta antara penataan ruang dengan pengelolaan sumber daya air. Jadi, pertumbuhan fisik perkotaan dapat menimbulkan konflik terhadap lingkungan perkotaan, salah satunya lingkungan air bersih.

Sementara itu menurut Yuri \& Nurcahyo (2013), konsep kualitas merupakan sebuah konsep yang di dalamnya terdapat hubungan antara kepuasan manusia dengan kebutuhannya. Permasalahan lingkungan air bersih di Jatinangor menjadikan masyarakat memiliki nilai dan sikap kritis terhadap kepuasan pemenuhan kebutuhan akan air bersih tersebut. Maka dari itu, masyarakat Jatinangor menjadi komponen yang mengerti akan kualitas air bersih rumah tangga di Jatinangor. Lebih lanjut, partisipasi masyarakat Jatinangor dalam pengelolaan lingkungan air bersih sendiri masih kurang.

Kecamatan Jatinangor sebagai KSP Jawa Barat memiliki peranan dalam berbagai aspek kegiatan masyarakat untuk mendukung pengembangan kawasan. Pemerintah dalam kebijakannya telah mencanangkan arahan prioritas pada bidang lingkungan hidup dan sosial. Pada faktanya, Jatinangor mengalami pertumbuhan penduduk dan pembangunan fisik yang pesat sehingga konversi lahan sangat tinggi. Selain itu, Jatinangor juga memiliki permasalahan lingkungan air bersih. Maka dari itu, pada penelitian ini penulis ingin mengetahui pengaruh pertumbuhan penduduk dan guna lahan terhadap kualitas air bersih rumah tangga di Jatinangor.

\section{KAJIAN PUSTAKA}

Menurut Mirsa (2011) dan Rukmana et al (1993), suatu area perkotaan memiliki beberapa karakteristik, di antaranya adalah jumlah penduduk dan kepadatan penduduk yang cederung meningkat dan lebih tinggi bila dibandingkan dengan daerah sekitarnya. Kepadatan penduduk dapat diukur dengan melihat rasio perbandingan antara jumlah penduduk dengan luas wilayah (Yunus, 2005). Jadi, suatu perkotaan memiliki ciri khas yaitu pertumbuhan jumlah dan kepadatan penduduk yang meningkat, sedangkan kepadatan penduduk sendiri merupakan perbandingan antara jumlah penduduk dengan luas wilayah.

Pertumbuhan penduduk yang meningkat menyebabkan kebutuhan lahan sebagai ruang aktivitas penduduk semakin meningkat pula. Ketersediaan lahan yang terbatas akan berdampak pada pemenuhan kebutuhan permukiman pada masa yang akan datang. Salah satu pemenuhan kebutuhan penduduk yang akan terdampak secara signifikan oleh keterbatasan ketersediaan lahan adalah permukiman (Setyorini, 2012). Menurut Ellis, et al dalam Fritsche, et al, (2015), penggunaan lahan adalah karakteristik lingkungan, baik lingkungan fisik maupun lingkungan biologi yang digunakan manusia untuk aktivitasnya sehari-hari. Sementara itu Ritohardoyo (2013), menerangkan bahwa dalam proses analisis penggunaan lahan diawali dari identifikasi bentuk-bentuk penggunaan lahan terbangun dan non terbangun.

Lebih lanjut, konsep kualitas adalah sesuatu yang mempengaruhi kepuasan pelanggan terhadap kebutuhannya. Jadi, konsep kualitas merupakan konsep yang di dalamnya terdapat hubungan antara kepuasan manusia dengan kebutuhannya (Yuri \& Nurcahyo, 2013). Air bersih rumah tangga digunakan untuk keperluan rumah tangga, di antaranya untuk memenuhi kebutuhan minum, mandi, dan memasak (WHO dalam Howard \& Bartram, 2003). Jadi, kualitas air bersih rumah tangga merupakan kepuasan manusia terhadap kebutuhan air bersih sehari-hari yakni untuk keperluan minum, mandi, dan memasak. Lebih lanjut terkait hal tersebut, Kodoatie \& Sjarief (2010), menerangkan bahwa sistem infrastruktur air bersih merupakan wujud air di dalam struktur ruang. Sementara itu, sumber air tanah di antaranya 
meliputi; mata air, sumur dangkal, dan sumur bor dalam. Jadi, kebutuhan air bersih rumah tangga berasal dari infrastruktur air bersih permukiman seperti PDAM, dan sumber air tanah (mata air, sumur dangkal/dalam).

Pada kesimpulannya pertumbuhan penduduk berdampak pada konversi lahan menjadi terbangun, khususnya lahan permukiman. Kebutuhan lahan permukiman yang meningkat dengan segala aktivitas penduduk di dalamnya, menjadikan kebutuhan air bersih sebagai kebutuhan yang vital bagi penduduk menjadi meningkat pula.

\section{METODE PENELITIAN}

Penelitian ini merupakan penelitian kuantitatif dengan pendekatan penelitian deduktif. Penelitian kuantitatif merupakan metode ilmiah yang terukur, objektif, rasional, dan sistematis. Penelitian jenis ini menggunakan data berupa angka-angka dan analisis yang menggunakan statistik. Jadi, pendekatan metode penelitian kuantitatif merupakan metode ilmiah yang menggunakan data angka serta analisis statistik, supaya dapat mengukur secara rasional, sistematis, dan objektif (Sugiyono, 2009). Lebih lanjut, pendekatan deduktif adalah pendekatan yang menguji teori dengan fakta/data lapangan untuk memecahkan permasalahan penelitian serta mencapai tujuan penelitian (Silalahi, 2010).

Penelitian ini memiliki beberapa variabel penelitian. Variabel penelitian adalah objek pengamatan di dalam penelitian yang berperan terhadap peristiwa/gejala yang akan diteliti (Suryabrata, 2006). Variabel pada penelitian ini adalah sebagai berikut:

\section{a. Kepadatan Penduduk}

Kepadatan penduduk mempengaruhi kualitas air bersih rumah tangga. Bila kepadatan penduduk meningkat maka konversi lahan pun meningkat pula. Hal tersebut menyebabkan lahan penyimpan air berkurang. Standar Nasional Indonesia (SNI) tentang Tata Cara Perencanaan Lingkungan Perumahan di Perkotaan (2004), menerangkan bahwa kepadatan penduduk diukur melalui indikator jumlah penduduk dibagi dengan indikator luas daerah (lihat Tabel 1). Lebih lanjut, Badan Pusat Statistik menjelaskan perhitungannya sebagai berikut:

\section{$\mathrm{Kp}=\mathrm{P} / \mathrm{A}$}

Keterangan: $\mathrm{Kp}=$ kepadatan penduduk (jiwa/km²), $\mathrm{P}=$ jumlah penduduk (jiwa), $\mathrm{A}=$ luas daerah $\left(\mathrm{km}^{2}\right)$.

Tabel 1. Indikator Kepadatan Penduduk

Variabel Indikator

Kepadatan $\quad \mathrm{Kp}^{1}>\mathrm{Kp}^{0}$, berarti terjadi peningkatan kepadatan penduduk pada tahun $\mathrm{Kp}^{1}$ dibandingkan dengan tahun Penduduk $\quad \mathrm{Kp}{ }^{0}$

$\mathrm{K} p^{1}=\mathrm{Kp}^{0}$, berarti tidak terjadi perubahan kepadatan penduduk pada tahun $\mathrm{Kp}^{1}$ dan $\mathrm{Kp}{ }^{0}$

$\mathrm{Kp}^{1}<\mathrm{Kp}^{0}$, berarti terjadi penurunan kepadatan penduduk pada tahun $\mathrm{Kp}^{1}$ dibandingkan dengan tahun $\mathrm{Kp} \mathrm{p}^{0}$

Sumber: Standar Nasional Indonesia, 2004; Badan Pusat Statistik (n.d)

\section{b. Penggolongan Penggunaan Lahan}

Perubahan penggunaan lahan mempengaruhi kualitas air bersih rumah tangga. Konversi lahan dari lahan non terbangun menjadi lahan terbangun menyebabkan lahan penyimpan air berkurang. Menurut Ritohardoyo (2013), proses analisis penggunaan lahan diawali dari identifikasi bentuk-bentuk penggunaan lahan seperti lahan terbangun dan lahan non terbangun. Berikut merupakan indikator penggolongan penggunaan lahan (lihat Tabel 2).

Tabel 2. Indikator Penggolongan Penggunaan Lahan

\begin{tabular}{cl}
\hline Variabel & \multicolumn{1}{c}{ Indikator } \\
\hline Penggolongan Penggunaan Lahan & Luasan penggunaan lahan terbangun $(\mathrm{Ha})$ \\
& Luasan penggunaan lahan non terbangun $(\mathrm{Ha})$ \\
\hline
\end{tabular}

Sumber: Ritohardoyo, 2013 


\section{c. Sumber Air}

Sumber air mempengaruhi kualitas air bersih rumah tangga. Bila kualitas sumber air menurun, maka menyebabkan pemenuhan akan air bersih rumah tangga tidak optimal. Sistem infrastruktur air bersih merupakan wujud air di dalam struktur ruang. Sementara itu, sumber air tanah di antaranya meliputi; mata air, sumur dangkal, dan sumur bor dalam (Kodoatie \& Sjarief, 2010). Jadi, sumber air bersih rumah tangga berasal dari infrastruktur air bersih permukiman seperti PDAM, dan sumber air tanah (mata air, sumur dangkal/dalam). Berikut merupakan indikator sumber air (lihat Tabel 3).

Tabel 3. Indikator Sumber Air

\begin{tabular}{cl}
\hline Variabel & \multicolumn{1}{c}{ Indikator } \\
\hline Sumber Air & Kondisi dan kualitas air tanah (sumur dangkal/dalam) \\
& Kondisi dan kualitas air PDAM \\
\hline
\end{tabular}

Sumber: Kodoatie \& Sjarief, 2010

\section{d. Pengelolaan Air}

Pengelolaan air mempengaruhi kualitas air bersih rumah tangga. Bila pengelolaan air tidak baik, maka menyebabkan pemenuhan akan air bersih tidak optimal. Pengelolaan keberlanjutan air bersih dilakukan dengan cara pengintegrasian pasokan air bersih (European Union, 2008). Sistem infrastruktur air bersih merupakan wujud air didalam struktur ruang. Sementara itu, sumber air tanah di antaranya meliputi; mata air, sumur dangkal, dan sumur bor dalam (Kodoatie \& Sjarief, 2010). Jadi, pengintegrasian pasokan air bersih rumah tangga berasal dari infrastruktur air bersih permukiman PDAM dan sumber air tanah. Berikut merupakan indikator pengelolaan air (lihat Tabel 4).

Tabel 4. Indikator Pengelolaan Air

\begin{tabular}{cc}
\hline Variabel & Indikator \\
\hline Pengelolaan Air & $\begin{array}{l}\text { Jangkauan pelayanan air PDAM di masyarakat } \\
\text { Pengguna air tanah di masyarakat }\end{array}$ \\
\hline Sumber: European Union, 2008; Kodoatie \& Sjarief, 2010
\end{tabular}

Penelitian ini menggunakan teknik pengumpulan data primer berupa observasi dan kuesioner; serta data sekunder. Teknik pengumpulan data sekunder adalah teknik pengumpulan data dengan melakukan pencarian data ke pihak lain seperti badan/lembaga pemerintahan ataupun swasta (Pasaribu, 2013). Sementara itu, observasi merupakan kegiatan perekaman data menggunakan indera seperti mata dan telinga (Suwartono, 2014). Lebih lanjut, kuesioner merupakan instrumen survei pengumpulan data yang berfungsi sebagai alat pengukuran terhadap variabel penelitian. Terdapat dua jenis kuesioner yakni di antaranya kuesioner tertutup dan kuesioner terbuka. Pada penelitian ini menggunakan jenis kuesioner tertutup. Kuesioner tertutup adalah kuesioner yang berisi opsi-opsi yang sudah ditentukan sebelumnya oleh peneliti. Responden hanya tinggal memilih opsi yang paling sesuai dengan pendapat dirinya (Suwartono, 2014).

Kuesioner pada penelitian ini memiliki responden sejumlah 99 responden Kepala Keluarga (KK). Penentuan responden menggunakan rumus Slovin. Pemakaian rumus Slovin memiliki syarat yaitu adanya anggota populasi yang diketahui jumlahnya (populasi terhingga). Selain populasi, syarat selanjutnya adalah menentukan persentase tingkat toleransi kesalahan (Amirin, 2011). Pada penelitian ini memiliki jumlah populasi sebesar 18.383 KK (BPS, 2016), sedangkan tingkat toleransi kesalahan adalah sebesar $10 \%$.

\begin{tabular}{|c|c|}
\hline$n=N$ & $n=18.383$ \\
\hline $1+\mathrm{N} \cdot \mathrm{e}^{2}$ & $\left(1+\left(18.383\left(0.1^{2}\right)\right)\right)$ \\
\hline
\end{tabular}

Ket:

$\mathrm{n}=$ ukuran sampel

$\mathrm{N}=$ jumlah populasi

$\mathrm{e}=$ tingkat kesalahan maksimum (toleransi kesalahan)

Penelitian ini menggunakan teknik analisis statistik deskriptif, skoring dan spatial overlay. Statistik deskriptif merupakan teknik pengolahan data statistik menjadi berbagai bentuk chart dengan maksud mempermudah pemahaman 
pembaca (Subagyo, 2003). Statistik deskriptif dilakukan dalam analisis pertumbuhan penduduk Jatinangor, analisis guna lahan Jatinangor, dan analisis perkembangan kondisi dan pengelolaan air bersih Jatinangor.

Sementara itu, skoring dalam penelitian ini menggunakan metode Skala Likert. Skala Likert merupakan metode penskalaan dengan menempatkan serangkaian stimulus dalam suatu kontinum poin. Metode penskalaan berpusat pada respons subjek yang dibuat dalam suatu rentang poin tertentu (Setiawati, et al, 2013). Skoring dilakukan dalam analisis permasalahan kualitas air bersih rumah tangga berdasarkan persepsi masyarakat Jatinangor. Berikut merupakan langkah-langkah skoring dengan Skala Likert:

- Menentukan jumlah perkalian antara total jumlah responden yang memilih di antara ke lima poin tersebut dengan ke lima skor.

- Menjumlahkan hasil perhitungan dari ke lima poin.

- Menentukan interpretasi skor perhitungan dengan menghitung skor tertinggi dan skor terendah.

$Y=$ skor tertinggi Likert $\mathrm{x}$ jumlah responden

$X=$ skor terendah Likert $x$ jumlah responden

- Menentukan interval persentase skor (\%) ke lima poin.

$$
\text { I = } 100 / \text { iumlah skor Likert }
$$

- Menghitung hasil akhir.

Rumus Indeks $=(($ total skor-X $) /(\mathrm{Y}-\mathrm{X})) \times 100$

Lebih lanjut, spatial overlay menggunakan Sistem Informasi Geografi (SIG) yang mengintegrasikan data dari lapisanlapisan yang berbeda (Handayani, et al, 2005). Spatial overlay dilakukan dalam analisis pengaruh pertumbuhan penduduk dan guna lahan terhadap kualitas air bersih rumah tangga Jatinangor. Analisis tersebut memiliki 3 (tiga) input lapisan data yakni: peta hasil analisis pertumbuhan dan kepadatan penduduk, peta hasil analisis pertumbuhan lahan terbangun, dan peta hasil skor per kelurahan/desa terkait kualitas air bersih rumah tangga.

\section{HASIL DAN PEMBAHASAN}

\subsection{STATISTIK DESKRIPTIF}

\subsubsection{ANALISIS PERTUMBUHAN PENDUDUK JATINANGOR}

Tabel 5. Kepadatan Penduduk Kecamatan Jatinangor Tahun 2011-2016

\begin{tabular}{|c|c|c|c|c|c|c|c|c|}
\hline \multirow{2}{*}{ No. } & \multirow{2}{*}{ Kelurahan/Desa } & \multirow{2}{*}{ Luas Daerah $\left(\mathrm{km}^{2}\right)$} & \multicolumn{6}{|c|}{ Kepadatan Penduduk (jiwa/km²) } \\
\hline & & & 2011 & 2012 & 2013 & 2014 & 2015 & 2016 \\
\hline 1. & Cipacing & 1,79 & $9.029,1$ & $9.272,1$ & $8.000,6$ & $9.373,2$ & $9.497,2$ & 9.695 \\
\hline 2. & Sayang & 2,32 & $4.161,2$ & $4.273,3$ & $3.825,9$ & $4.102,6$ & $4.104,3$ & $4.124,1$ \\
\hline 3. & Mekargalih & 1,2 & $6.516,7$ & $6.691,7$ & 6.000 & $6.569,2$ & $6.609,2$ & $6.680,8$ \\
\hline 4. & Cinta Mulya & 1,34 & $6.661,9$ & $6.841,8$ & $5.335,1$ & $6.166,4$ & $6.073,9$ & $6.046,3$ \\
\hline 5. & Cisempur & 1,6 & $4.934,4$ & $5.066,9$ & $5.018,8$ & $5.181,9$ & 5.265 & $5.365,6$ \\
\hline 6. & Jatimukti & 1,9 & $2.798,4$ & $2.873,7$ & $2.762,6$ & 2.790 & $2.798,9$ & $2.816,3$ \\
\hline 7. & Jatiroke & 2,09 & $2.738,3$ & 2.812 & $3.084,2$ & $2.770,8$ & $2.790,4$ & $2.823,4$ \\
\hline 8. & Hegarmanah & 3,31 & $4.548,3$ & 4.671 & $2.995,2$ & $4.893,4$ & $5.001,2$ & $5.354,7$ \\
\hline 9. & Cikeruh & 2,13 & $6.373,2$ & $6.545,1$ & $4.631,5$ & $6.653,5$ & $6.750,2$ & $7.040,8$ \\
\hline 10. & Cibeusi & 1,84 & $5.578,8$ & $5.729,3$ & $5.874,5$ & $5.126,1$ & $5.040,2$ & $5.284,8$ \\
\hline 11. & Cileles & 3,2 & $1.740,3$ & $1.787,2$ & $1.879,4$ & $1.723,8$ & $1.726,3$ & $1.735,3$ \\
\hline 12. & Cilayung & 3,48 & $1.408,6$ & $1.446,6$ & $1.416,4$ & $1.363,2$ & $1.357,8$ & 1.356 \\
\hline & ec. Jatinangor & 26,2 & $4.231,5$ & $4.345,4$ & $3.771,1$ & $4.270,5$ & $4.298,5$ & 4.412 \\
\hline
\end{tabular}

Sumber: BPS Kab. Sumedang, 2017

Berdasarkan Tabel 5, dapat diketahui bahwa kelurahan/desa dengan kepadatan penduduk tertinggi pada tahun 2011 yakni Cipacing sebesar 9.029,1 jiwa/km², disusul dengan Cinta Mulya dengan kepadatan penduduk sebesar 6.661,9 
jiwa $/ \mathrm{km}^{2}$. Sementara itu, kelurahan/desa dengan kepadatan penduduk tertinggi pada tahun 2016 yakni Cipacing sebesar $9.695 \mathrm{jiwa} / \mathrm{km}^{2}$, disusul dengan Cikeruh dengan kepadatan penduduk sebesar 7.040,8 jiwa/km².

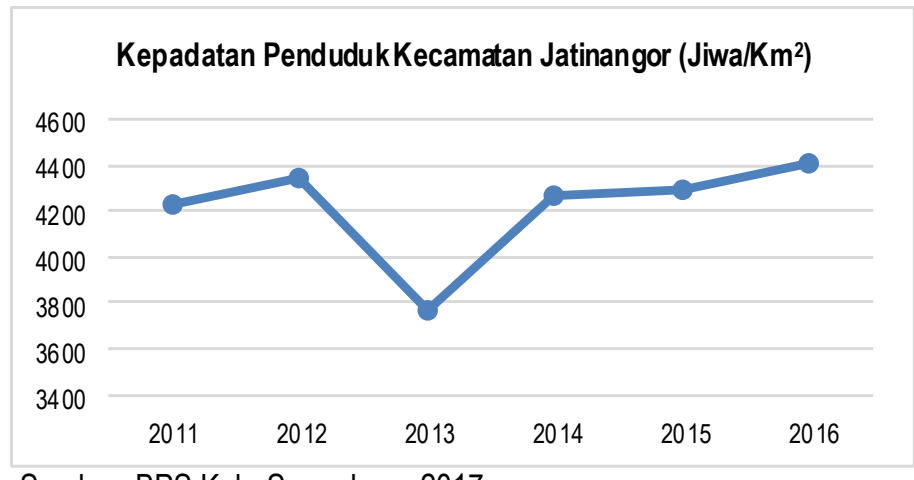

Sumber: BPS Kab. Sumedang, 2017

Gambar 1. Kepadatan Penduduk Kecamatan Jatinangor Tahun 2011-2016

Berdasarkan grafik tersebut, dapat diketahui bahwa kepadatan penduduk Jatinangor pada tahun 2011 adalah sebesar 4.231,5 jiwa/km². Sementara itu, kepadatan penduduk pada tahun 2016 sebesar $4.412 \mathrm{jiwa} / \mathrm{km}^{2}$. Terjadi penambahan kepadatan penduduk pada tahun 2011 hingga tahun 2016 sejumlah 180,5 jiwa/km². Akan tetapi, pada tahun 2013 kepadatan penduduk Jatinangor menurun signifikan pada angka 3.771,1 jiwa/km² (lihat Gambar 1).

Pada kesimpulannya, kepadatan penduduk tahun 2016 lebih besar dari kepadatan penduduk tahun 2011. Hal tersebut menunjukkan bahwa terjadinya peningkatan kepadatan penduduk pada Kecamatan Jatinangor. Peningkatan tersebut berdampak pada konversi lahan menjadi terbangun.

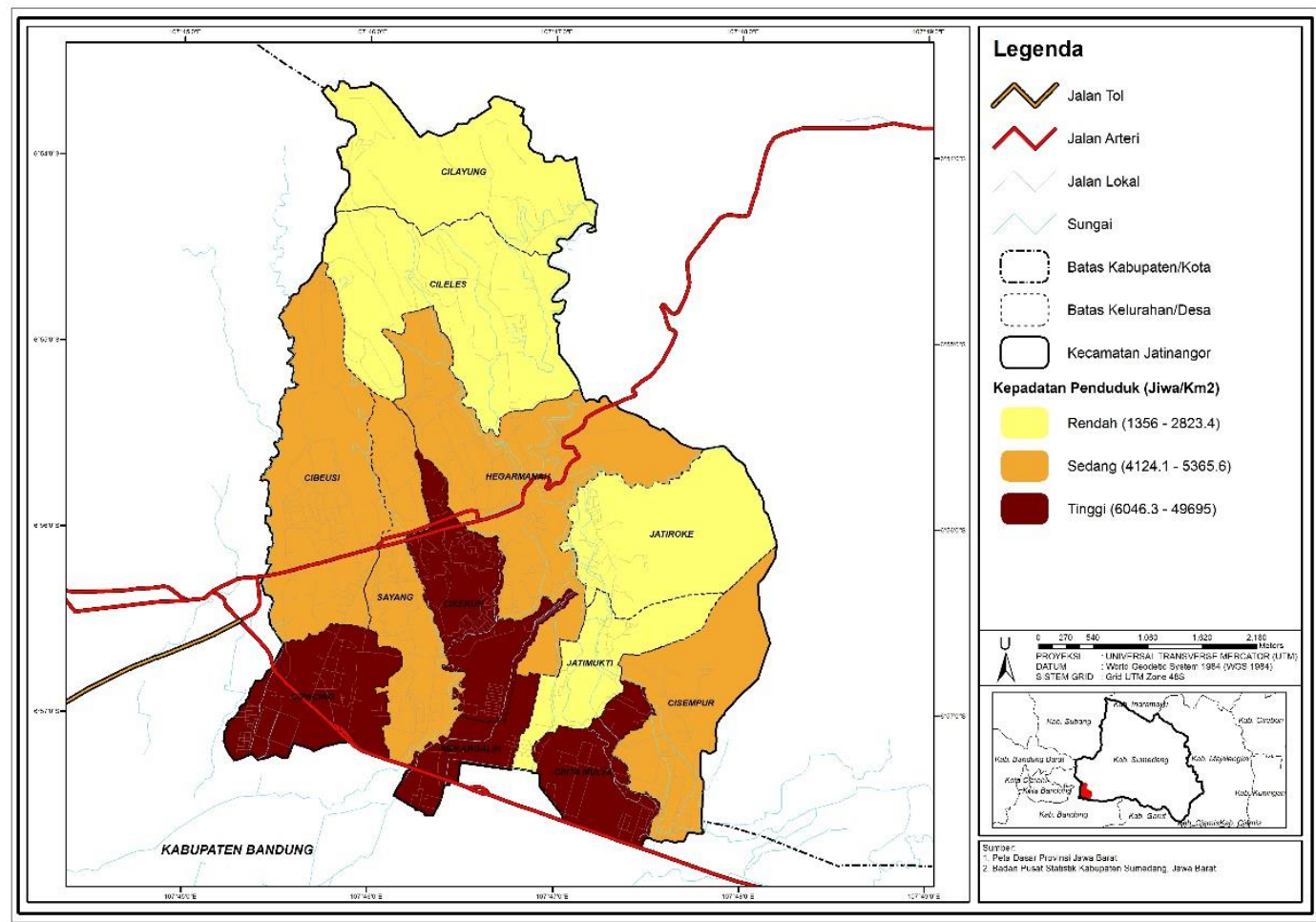

Gambar 2. Peta Kepadatan Penduduk Tahun 2016

Berdasarkan peta tersebut, menunjukkan bahwa kepadatan penduduk tahun 2016 dengan klasifikasi tinggi terdapat pada Kelurahan/Desa Cipacing, Cikeruh, Mekargalih dan Cinta Mulya. Sementara itu, kepadatan penduduk dengan klasifikasi sedang terdapat pada Kelurahan/Desa Cibeusi, Sayang, Hegarmanah, dan Cisempur. Lebih lanjut, kepadatan penduduk dengan klasifikasi rendah terdapat pada Kelurahan/Desa Cilayung, Cileles, Jatiroke, dan Jatimukti (lihat Gambar 2). 


\subsubsection{ANALISIS GUNA LAHAN JATINANGOR}

Tabel 6. Penggolongan Luasan Penggunaan Lahan Non Terbangun dan Lahan Terbangun Kecamatan Jatinangor Tahun 2014-2016

\begin{tabular}{|c|c|c|c|c|c|}
\hline \multirow{2}{*}{ No. } & \multirow{2}{*}{ Penggolongan Luasan Penggunaan Lahan (Ha) } & \multicolumn{3}{|c|}{ Tahun } & \multirow{2}{*}{ Rata-Rata Perubahan Luasan $(\mathrm{Ha})$} \\
\hline & & 2014 & 2015 & 2016 & \\
\hline \multicolumn{6}{|c|}{ Lahan Non Terbangun } \\
\hline 1. & Kebun/Ladang & 931,2 & 833,1 & 754,9 & berkurang $88,15 \mathrm{Ha}$ per tahun \\
\hline 2. & Sawah & 823,2 & 703,4 & 670,9 & berkurang $76,15 \mathrm{Ha}$ per tahun \\
\hline 3. & Sungai/Danau/Waduk/Situ & & 1,8 & & - \\
\hline \multicolumn{5}{|c|}{ Lahan Terbangun } & Perubahan Th. 2015-2016 \\
\hline 1. & Permukiman & & 812,71 & 828,32 & bertambah $15,61 \mathrm{Ha}$ \\
\hline 2. & Industri & $863,7^{(*)}$ & 158,98 & 186,82 & bertambah $27,84 \mathrm{Ha}$ \\
\hline 3. & Sarana & & 66,84 & 109,49 & bertambah $42,65 \mathrm{Ha}$ \\
\hline 4. & Prasarana Jalan & & 42,97 & 67,67 & bertambah $24,7 \mathrm{Ha}$ \\
\hline
\end{tabular}

$\left.{ }^{*}\right)$ Data tidak tersedia per jenis penggunaan lahan terbangun

Sumber: Bappeda Provinsi Jawa Barat, 2017

Berdasarkan tabel tersebut, penggunaan lahan non terbangun terbesar luasannya yaitu jenis penggunaan lahan kebun/ladang sejumlah 754,9-931,2 ha. Dilain pihak, penggunaan lahan non terbangun terkecil luasannya yaitu jenis penggunaan lahan sungai/danau/waduk/situ sejumlah 1,8 ha. Pada kesimpulannya, penggunaan lahan non terbangun dari tahun 2014 hingga tahun 2016 mengalami penurunan sejumlah 76,15-88,15 ha per tahunnya.

Penggunaan lahan terbangun terbesar luasannya menurut data tahun 2015-2016 yaitu jenis penggunaan lahan permukiman sejumlah $812,71-828,32$ ha, sedangkan penggunaan lahan terbangun terkecil luasannya yaitu jenis penggunaan lahan prasarana jalan sejumlah 42,97-67,67 ha. Pada kesimpulannya, penggunaan lahan terbangun mengalami peningkatan sejumlah 15,61-42,65 ha per tahunnya dapat dilihat pada Tabel 6 .

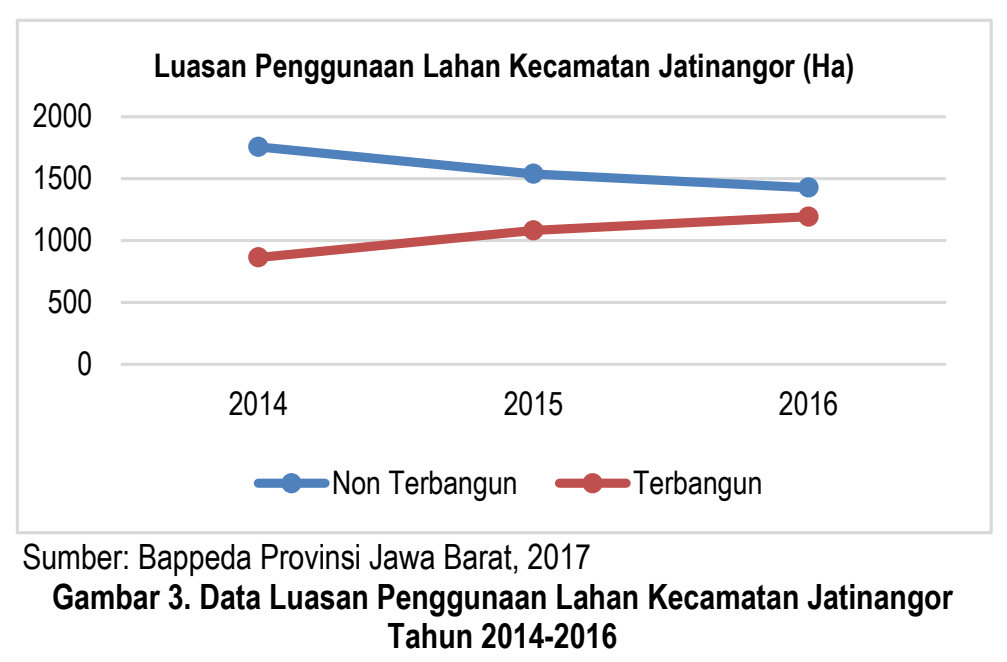

Berdasarkan grafik tersebut, menunjukkan bahwa penggunaan lahan non terbangun mengalami penurunan dengan rata-rata penurunan sejumlah 82,15 ha per tahunnya. Sedangkan, penggunaan lahan terbangun mengalami peningkatan dengan rata-rata peningkatan sejumlah 164,3 ha per tahunnya (lihat Gambar 3). Hal tersebut menunjukkan bahwa terjadinya konversi lahan dari lahan non terbangun ke lahan terbangun di Kecamatan Jatinangor. 


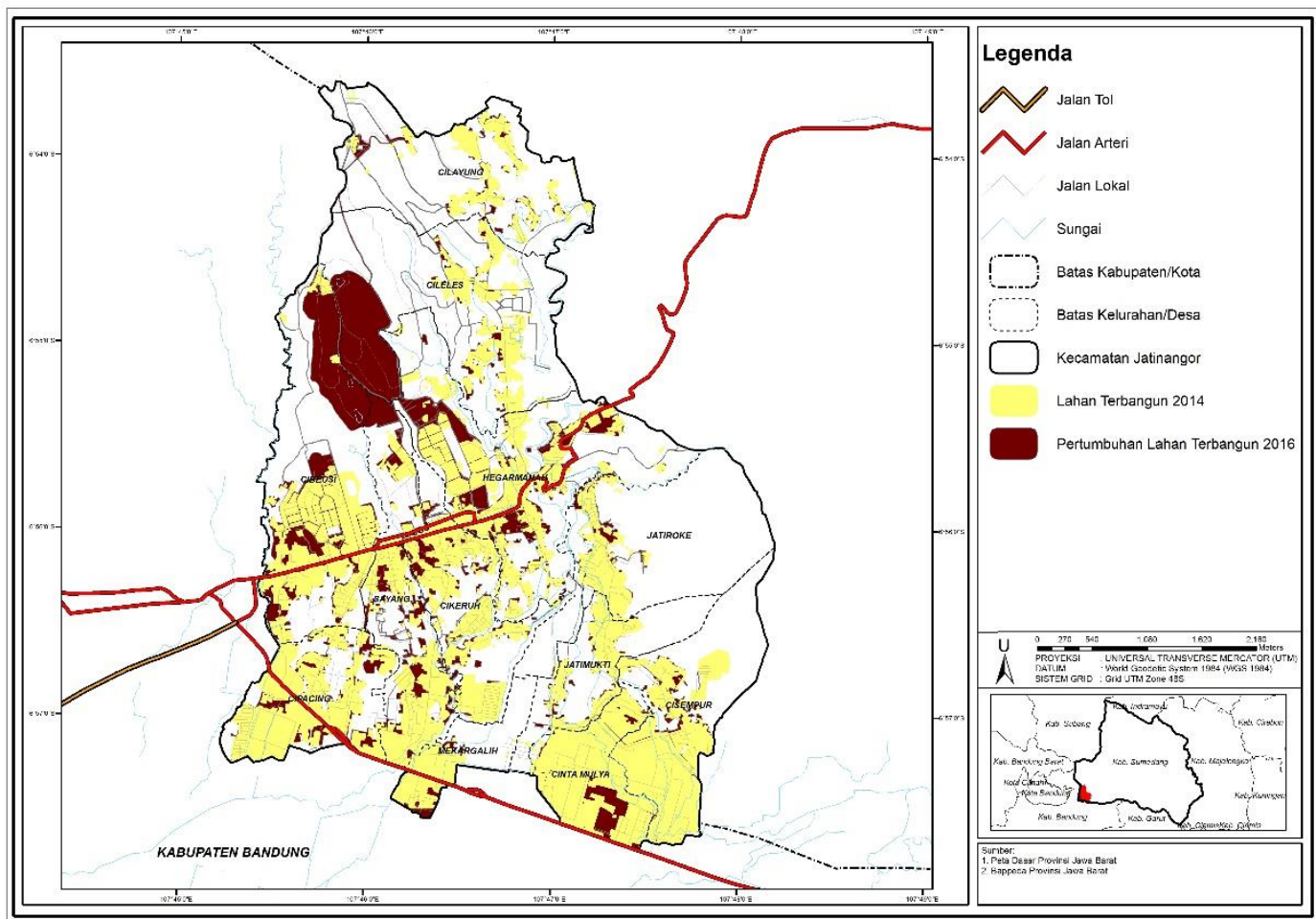

Sumber: Bappeda Provinsi Jawa Barat, 2017

Gambar 4. Peta Pertumbuhan Lahan Terbangun Kecamatan Jatinangor Tahun 2014-2016

Berdasarkan peta tersebut, menunjukkan bahwa penggunaan lahan terbangun dalam kurun waktu dua tahun mengalami peningkatan yang signifikan di Kecamatan Jatinangor (lihat Gambar 4). Lahan terbangun yang tumbuh pesat berupa sarana pendidikan tinggi, sarana apartemen/hotel, kompleks perumahan/permukiman, permukiman sewa (kost), sarana perdagangan jasa, dan industri. Peningkatan jumlah lahan terbangun menyebabkan aktivitas di lahan terbangun tersebut meningkat, hal itu menjadikan kebutuhan air bersih sebagai kebutuhan yang vital bagi penduduk menjadi meningkat pula.

\subsubsection{ANALISIS PERKEMBANGAN KONDISI DAN PENGELOLAAN AIR BERSIH JATINANGOR}

Tabel 7. Kedudukan Muka Air Tanah Kecamatan Jatinangor Tahun 2000-2011

\begin{tabular}{ccccc} 
No. & Tahun & $\begin{array}{c}\text { Muka Air Tanah } \\
(\mathbf{m} \text { bmt) })^{*}\end{array}$ & $\begin{array}{c}\text { Nilai Tengah Muka } \\
\text { Air Tanah (m bmt) }\end{array}$ & Keterangan \\
\hline 1. & 2000 & $6,59-63,12$ & 35 & \\
2. & 2004 & $7,93-68,79$ & 38,4 & Muka air tanah turun \\
3. & 2006 & $21,28-68,51$ & 44,9 & \\
4. & 2010 & $18,58-88,60$ & 53,6 & \\
5. & 2011 & $22,15-99,93$ & 61 & \\
\hline
\end{tabular}

(*) meter dibawah permukaan tanah

Sumber: Badan Geologi Pusat Air Tanah dan Geologi Tata Lingkungan Kementerian Energi dan Sumber Daya Mineral, 2011

Berdasarkan Tabel 7, dapat diketahui bahwa pada tahun 2000 kedudukan muka air tanah berada pada kedalaman 6,59-63,12 m bmt (meter di bawah permukaan tanah). Sementara itu, pada pada tahun 2011 kedudukan muka air tanah turun hingga kedalaman 22,15-99,93 m bmt. Rata-rata penurunan muka air tanah yakni sebesar 3,89-9,20 m bmt per tahunnya. Hal tersebut menunjukkan bahwa Jatinangor mengalami penurunan muka air tanah yang signifikan.

Tabel 8. Kondisi Pencemaran Air Tanah Kecamatan Jatinangor Tahun 2000-2011

\begin{tabular}{cccccccc}
\hline No. & Tahun & $\begin{array}{c}\text { Nilai Tengah Muka } \\
\text { Air Tanah }(\mathbf{m} \text { bmt) }\end{array}$ & $\begin{array}{c}\text { Tingkat Penurunan } \\
\text { Muka Air Tanah }(\%)\end{array}$ & $\begin{array}{c}\text { Zat Padat } \\
(\mathbf{m g} / \mathbf{l})\end{array}$ & $\begin{array}{c}\text { DHL(*) } \\
(\mathbf{S} / \mathbf{c m})\end{array}$ & $\begin{array}{c}\text { Dampak } \\
\text { Lingkungan }\end{array}$ & $\begin{array}{c}\text { Keterangan } \\
\text { Kategori }\end{array}$ \\
\hline 1. & 2000 & 35 & $60-80$ & $10.000-100.000$ & 5.000 & Amblesan Tanah & Air Tanah Kritis \\
2. & 2004 & 38,4 & $60-80$ & $10.000-100.000$ & 5.000 & & Air Tanah Kritis
\end{tabular}




\begin{tabular}{cccccccc}
\hline No. & Tahun & $\begin{array}{c}\text { Nilai Tengah Muka } \\
\text { Air Tanah (m bmt) }\end{array}$ & $\begin{array}{c}\text { Tingkat Penurunan } \\
\text { Muka Air Tanah }(\%)\end{array}$ & $\begin{array}{c}\text { Zat Padat } \\
(\mathbf{m g} / \mathbf{l})\end{array}$ & $\begin{array}{c}\text { DHL() } \\
(\mathbf{S} / \mathbf{c m})\end{array}$ & $\begin{array}{c}\text { Dampak } \\
\text { Lingkungan }\end{array}$ & $\begin{array}{c}\text { Keterangan } \\
\text { Kategori }\end{array}$ \\
\hline 3. & 2006 & 44,9 & $60-80$ & $10.000-100.000$ & 5.000 & & Air Tanah Kritis \\
4. & 2010 & 53,6 & $60-80$ & $10.000-100.000$ & 5.000 & & Air Tanah Kritis \\
5. & 2011 & 61 & $>80$ & $>100.000$ & $>5.000$ & Air Tanah Rusak \\
\hline
\end{tabular}

(") Daya Hantar Listrik (semakin banyak zat organik yang terkandung di dalam air, maka semakin besar daya hantar listriknya). Sumber: Badan Geologi Pusat Air Tanah dan Geologi Tata Lingkungan Kementerian Energi dan Sumber Daya Mineral, 2011

Berdasarkan tabel tersebut dapat diketahui bahwa pada tahun 2000-2010 memiliki tingkat penurunan muka air tanah sebesar $60-80 \%$, kenaikan zat padat terlarut sebesar 10.000-100.000 mg/l, daya hantar listrik sebesar $5.000 \mathrm{~S} / \mathrm{cm}$, dampak lingkungan amblesan tanah, dan kategori air tanah kritis.

Sementara itu, pada tahun 2011 memiliki tingkat penurunan muka air tanah sebesar $>80 \%$, kenaikan zat padat terlarut sebesar $>100.000 \mathrm{mg} / \mathrm{l}$, daya hantar listrik sebesar $>5.000 \mathrm{~S} / \mathrm{cm}$, dampak lingkungan amblesan tanah, dan kategori air tanah rusak.

Pada kesimpulannya, Jatinangor memiliki kondisi sumber air tanah yang menurun kualitasnya. Hal tersebut ditunjukkan dengan adanya penurunan kedudukan muka air tanah, peningkatan zat padat terlarut, dan dampak lingkungan amblesan tanah dapat dilihat pada Tabel 8.

Tabel 9. Data Debit Sumber Air PDAM Kecamatan Jatinangor Tahun 2011-2016

\begin{tabular}{ccccc}
\hline No. & Tahun & Mata Air Goa Walet & $\begin{array}{c}\text { Debit Air (L/dt) } \\
\text { Sumur Artesis Unpad I }\end{array}$ & Sumur Artesis Unpad II \\
\hline 1. & 2011 & 20 & 10 & 10 \\
2. & 2012 & 16 & 8 & 8 \\
3. & 2013 & 15 & 5 & 5 \\
4. & 2014 & 15 & 4,5 & 4,37 \\
5. & 2015 & 13 & 3,3 & 3,3 \\
6. & 2016 & 11 & 2,5 & 2,5 \\
\multicolumn{2}{c}{ Rata-Rata } & 1,8 & 1,5 & 1,5 \\
Penurunan Debit Air & & 1,6 & \\
per Tahunnya (L/dt) & & &
\end{tabular}

Berdasarkan tabel tersebut, dapat diketahui bahwa terdapat 3 (tiga) sumber air PDAM untuk melayani Kecamatan Jatinangor. Sumber air tersebut di antaranya mata air Goa Walet, serta sumur artesis Unpad I dan II. Sumber air tersebut mengalami penurunan debit air pada setiap tahunnya. Rata-rata penurunan debit air PDAM sumber mata air Goa Walet yakni sebesar 1,8 L/dt. Sedangkan, penurunan debit air pada sumur artesis Unpad I dan sumur artesis Unpad II masing-masing sebesar 1,5 L/dt (lihat Tabel 9).

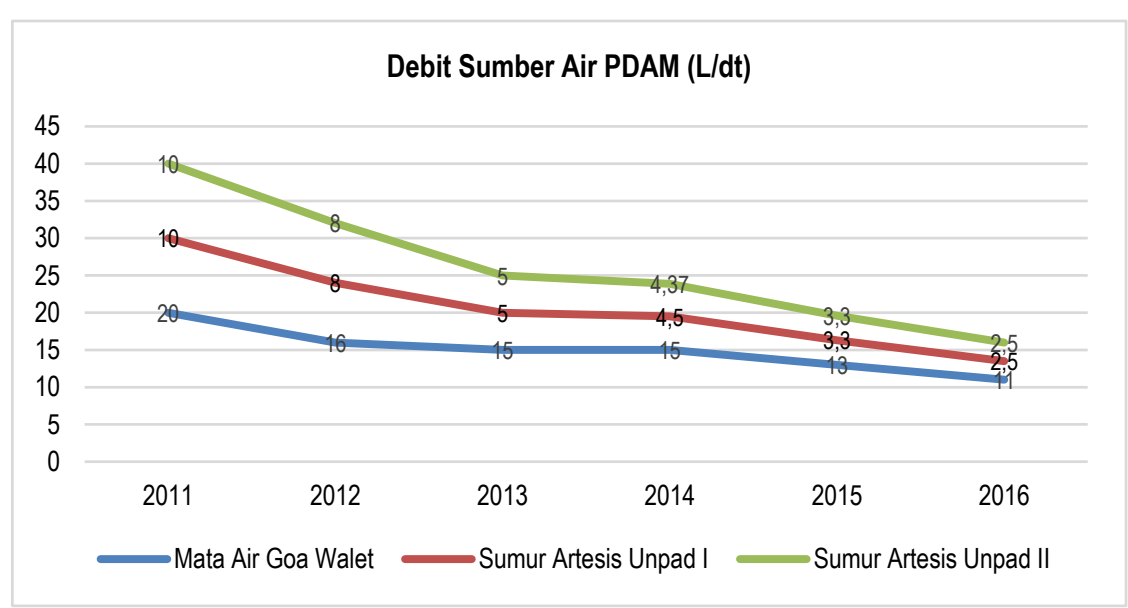

Sumber: PDAM Kab. Sumedang, 2017

Gambar 5. Data Debit Sumber Air PDAM Kecamatan Jatinangor Tahun 2011-2016 
Berdasarkan grafik tersebut, dapat diketahui bahwa dari tahun 2011 sampai dengan tahun 2016 terjadi penurunan debit sumber air PDAM. Rata-rata penurunan debit sumber air PDAM yakni sebesar 1,6 L/dt per tahunnya (lihat Gambar 5).

Berdasarkan hasil pembahasan di atas, dapat disimpulkan bahwa Kecamatan Jatinangor mengalami permasalahan lingkungan air bersih yakni di antaranya penurunan kedudukan muka air tanah dan penurunan debit sumber air PDAM.

Tabel 10. Data Pengguna Air PDAM dan Air Tanah Kecamatan Jatinangor Tahun 2011-2016

\begin{tabular}{ccccc}
\hline No. & Tahun & Jumlah KK & Jumlah Pengguna Air PDAM (KK) & Jumlah Pengguna Air Tanah (KK) \\
\hline 1. & 2011 & 55.432 & 1.891 & 53.541 \\
2. & 2012 & 40.921 & 1.881 & 39.040 \\
3. & 2013 & 25.906 & 1.874 & 24.032 \\
1. & 2014 & 27.394 & 1.860 & 25.534 \\
2. & 2015 & 18.383 & 1.855 & 16.528 \\
3. & 2016 & 27.349 & 1.852 & 23.497 \\
\hline
\end{tabular}

Sumber: PDAM Kab. Sumedang; BPS Kab. Sumedang, 2017

Berdasarkan data tersebut, dapat diketahui jumlah pengguna air PDAM yakni 1.852-1.891 KK. Sedangkan, jumlah pengguna air tanah yakni 16.528-53.541 KK. Pada tahun 2016 jumlah pengguna air PDAM sebesar 1.852 KK, sedangkan jumlah pengguna air tanah sebesar $23.497 \mathrm{KK}$ (lihat Tabel 10). Perbandingan jumlah pengguna air tanah 13 kali lebih besar dibandingkan jumlah pengguna air PDAM.

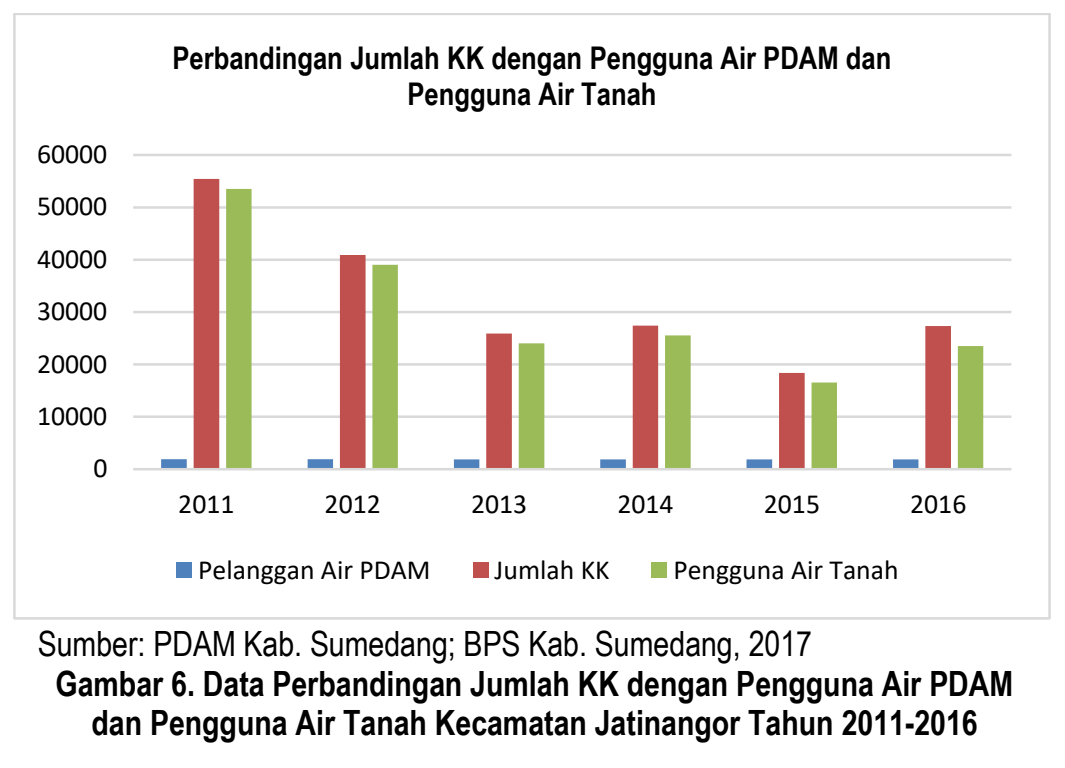

Berdasarkan grafik tersebut, pengguna sumber air PDAM hanya menjangkau 6,5\% dari jumlah keseluruhan (KK). Sedangkan, pengguna sumber air tanah mendominasi sebesar $92 \%$ dari jumlah keseluruhan (KK). Jumlah pengguna air PDAM menurun pada setiap tahunnya dengan rata-rata penurunan sebesar $8 \mathrm{KK}$ pada setiap tahunnya. Sementara itu, jumlah pengguna air tanah dari tahun ke tahun besarannya fluktuatif (naik-turun) dapat dilihat pada Gambar 6.

Tabel 11. Lembaga Sosial Masyarakat (LSM) Kecamatan Jatinangor Tahun 2011-2016

\begin{tabular}{ccccccc} 
No. & \multirow{2}{*}{ Tahun } & \multicolumn{5}{c}{ Bidang } \\
& Lingkungan & Hukum & Anak & Perempuan & Lainnya \\
\hline 1. & 2011 & - & - & - & - & 1 \\
2. & 2012 & - & - & - & - & 1 \\
3. & 2013 & - & - & - & - & 1 \\
4. & 2014 & - & - & - & - & 1 \\
5. & 2015 & - & - & - & - & 1 \\
6. & 2016 & - & - & - & - & 1 \\
\hline
\end{tabular}

Sumber: Badan Pusat Statistik Kabupaten Sumedang, 2017 
Selain pemerintah, masyarakat juga memiliki turut andil dalam pengelolaan lingkungan air bersih. Berdasarkan tabel tersebut, dapat diketahui bahwa pada tahun 2011 sampai dengan tahun 2016 Lembaga Sosial Masyarakat (LSM) bidang lingkungan tidak ada sama sekali di Kecamatan Jatinangor. Hal tersebut menunjukkan bahwa partisipasi dalam pengelolaan lingkungan air bersih dari masyarakat Jatinangor sendiri masih kurang (lihat Tabel 11).

Berdasarkan pembahasan di atas, dapat disimpulkan bahwa sumber air tanah maupun sumber air PDAM kondisinya menurun. Sementara itu, pengelolaan air bersih pada Kecamatan Jatinangor masih sangat kurang. Hal tersebut ditandai dengan penurunan kedudukan muka sumber air tanah, pencemaran sumber air tanah, penurunan debit sumber air PDAM, jangkauan pelayanan air PDAM ke masyarakat Jatinangor yang masih sangat kurang, dan kurangnya partisipasi masyarakat dalam pengelolaan lingkungan air.

\subsection{SKORING}

\subsubsection{ANALISIS PERMASALAHAN KUALITAS AIR BERSIH RUMAH TANGGA BERDASARKAN PERSEPSI MASYARAKAT JATINANGOR}

Tabel 12. Perhitungan Skoring Kualitas Air Bersih Masyarakat Jatinangor Tahun 2012 dan 2017

\begin{tabular}{|c|c|c|c|c|c|c|c|c|c|c|}
\hline \multirow[t]{2}{*}{ No. } & \multirow[t]{2}{*}{ Tahun } & \multirow{2}{*}{$\begin{array}{c}\text { Sumber Air Bersih Utama } \\
\text { Masyarakat }\end{array}$} & \multicolumn{5}{|c|}{$\begin{array}{c}\text { Perkalian Jumlah Jawaban dari } \\
\text { Berbagai Opsi }\end{array}$} & \multirow{2}{*}{$\begin{array}{l}\text { Total } \\
\text { Skor }\end{array}$} & \multirow[t]{2}{*}{ Hasil } & \multirow[t]{2}{*}{ Kategori } \\
\hline & & & 1 & 2 & 3 & 4 & 5 & & & \\
\hline 1. & \multirow{3}{*}{2012} & Air PDAM & 63 & 20 & 0 & 48 & 70 & 201 & $26 \%$ & Tidak setuju \\
\hline 2. & & Air Sumur Dangkal & 56 & 4 & 3 & 60 & 125 & 248 & $38 \%$ & Tidak setuju \\
\hline 3. & & Air Sumur Dalam & 85 & 4 & 0 & 8 & 50 & 147 & $12 \%$ & $\begin{array}{l}\text { Sangat tidak } \\
\text { setuju }\end{array}$ \\
\hline 4. & \multirow{3}{*}{2017} & Air PDAM & 61 & 36 & 18 & 24 & 40 & 179 & $20 \%$ & $\begin{array}{l}\text { Sangat Tidak } \\
\text { Setuju }\end{array}$ \\
\hline 5. & & Air Sumur Dangkal & 62 & 26 & 9 & 8 & 95 & 200 & $26 \%$ & Tidak Setuju \\
\hline 6. & & Air Sumur Dalam & 77 & 6 & 0 & 24 & 65 & 172 & $18 \%$ & $\begin{array}{c}\text { Sangat Tidak } \\
\text { Setuju }\end{array}$ \\
\hline
\end{tabular}

Berdasarkan Tabel 12, terdapat 3 (tiga) sumber air utama yang digunakan oleh masyarakat Jatinangor yakni di antaranya; air PDAM, air sumur dangkal, dan air sumur dalam. Dapat diketahui bahwa hasil skoring kualitas air bersih masuk kedalam kategori tidak setuju dan sangat tidak setuju. Hal tersebut menunjukkan bahwa kualitas air bersih rumah tangga menurut persepsi masyarakat Jatinangor kurang memadai untuk kebutuhan sehari-hari.

Tabel 13. Skor Kualitas Air Bersih per Kelurahan/Desa pada Kecamatan Jatinangor Tahun 2017

\begin{tabular}{|c|c|c|c|c|c|c|c|}
\hline \multirow[b]{2}{*}{ No. } & \multirow[b]{2}{*}{ Kelurahan/Desa } & \multirow[b]{2}{*}{$\begin{array}{c}\text { Jumlah } \\
\text { Responden }\end{array}$} & \multicolumn{3}{|c|}{ Jumlah Skor Kualitas Air Bersih } & \multirow[b]{2}{*}{$\begin{array}{l}\text { Jumlah } \\
\text { Skor Total }\end{array}$} & \multirow{2}{*}{$\begin{array}{l}\text { Rata-Rata Skor Kualitas } \\
\text { Air Bersih } \\
\text { (Jumlah Skor Total / Jumlah } \\
\text { Responden Kelurahan) }\end{array}$} \\
\hline & & & $\begin{array}{c}\text { Air } \\
\text { PDAM }\end{array}$ & $\begin{array}{l}\text { Air Sumur } \\
\text { Dangkal }\end{array}$ & $\begin{array}{l}\text { Air Sumur } \\
\text { Dalam }\end{array}$ & & \\
\hline 1. & Cipacing & 18 & 44 & 20 & 37 & 101 & 5,6 \\
\hline 2. & Sayang & 10 & 23 & 18 & 10 & 51 & 5,1 \\
\hline 3. & Mekargalih & 4 & 4 & 4 & 16 & 24 & 6 \\
\hline 4. & Cinta Mulya & 5 & 12 & 5 & 5 & 22 & 4,4 \\
\hline 5. & Cisempur & 11 & 11 & 49 & 11 & 71 & 6,5 \\
\hline 6. & Jatimukti & 4 & 4 & 14 & 4 & 22 & 5,5 \\
\hline 7. & Jatiroke & 5 & 11 & 5 & 13 & 29 & 5,8 \\
\hline 8. & Hegarmanah & 6 & 7 & 11 & 6 & 24 & 4 \\
\hline 9. & Cikeruh & 11 & 13 & 20 & 14 & 47 & 4,3 \\
\hline 10. & Cibeusi & 9 & 20 & 15 & 16 & 51 & 5,6 \\
\hline 11. & Cileles & 8 & 14 & 31 & 8 & 53 & 6,6 \\
\hline 12. & Cilayung & 8 & 16 & 8 & 32 & 56 & 7 \\
\hline
\end{tabular}

Berdasarkan Tabel 13, dapat diketahui bahwa kelurahan/desa dengan skor kualitas air bersih terendah yakni Kelurahan/Desa Hegarmanah. Sedangkan, kelurahan/desa dengan skor kualitas air bersih tertinggi yakni Kelurahan/Desa Cilayung. 


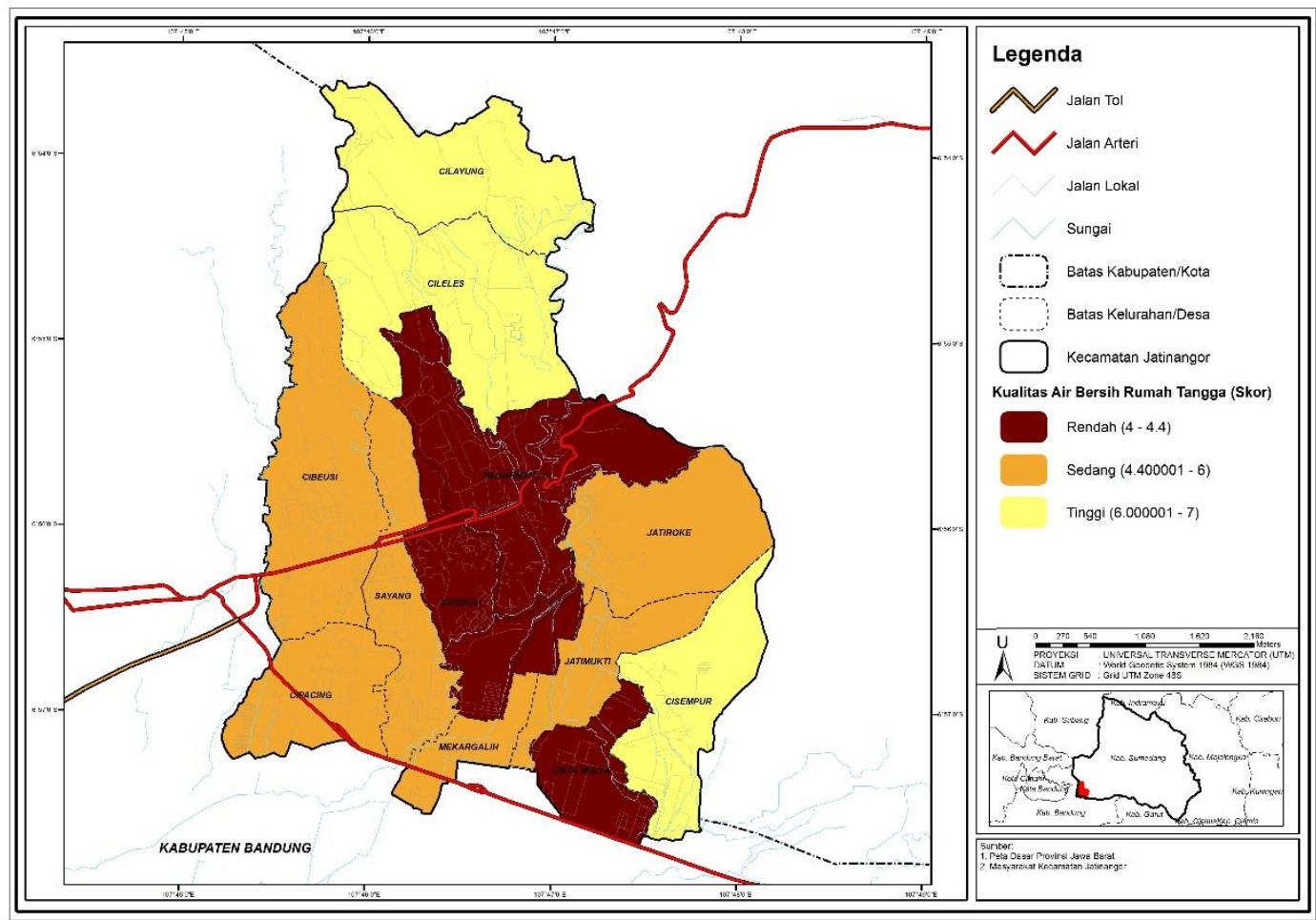

Gambar 7. Peta Kualitas Air Bersih Rumah Tangga Berdasarkan Persepsi Masyarakat Jatinangor Tahun 2017

Berdasarkan peta tersebut, kualitas air bersih rumah tangga memiliki 3 (tiga) kategori yakni di antaranya; kategori rendah, kategori sedang, dan kategori tinggi. Kelurahan/desa dengan kategori rendah di antaranya; Kelurahan/Desa Hegarmanah, Cikeruh, dan Cinta Mulya. Sedangkan kelurahan/desa dengan kategori sedang di antaranya; Kelurahan/Desa Cibeusi, Cipacing, Sayang, Mekargalih, Jatimukti, dan Jatiroke. Sementara itu, kelurahan/desa dengan kategori tinggi di antaranya; Kelurahan/Desa Cilayung, Cileles, dan Cisempur (lihat Gambar 7).

\subsection{SPATIAL OVERLAY}

\subsubsection{ANALISIS PENGARUH PERTUMBUHAN PENDUDUK DAN GUNA LAHAN TERHADAP KUALITAS AIR BERSIH RUMAH TANGGA JATINANGOR}

Didalam analisis ini berisi overlay hasil/kesimpulan dari analisis-analisis sebelumnya, berikut di antaranya:

- Terjadi peningkatan kepadatan penduduk.

- Pembangunan yang pesat sehingga konversi lahan dari lahan non terbangun ke lahan terbangun tinggi.

- Penurunan kedudukan muka sumber air tanah, pencemaran sumber air tanah, dan penurunan debit sumber air PDAM.

- Pengelolaan jangkauan pelayanan air PDAM ke masyarakat Jatinangor masih sangat kurang yakni sebesar 6,5\% dari jumlah keseluruhan KK.

- Kurangnya partisipasi masyarakat dalam pengelolaan lingkungan air.

- Kualitas air bersih menurut persepsi masyarakat Jatinangor kurang memadai untuk kebutuhan sehari-hari.

Berikut merupakan peta overlay dan peta output overlay pengaruh pertumbuhan penduduk dan guna lahan terhadap kualitas air bersih rumah tangga: 


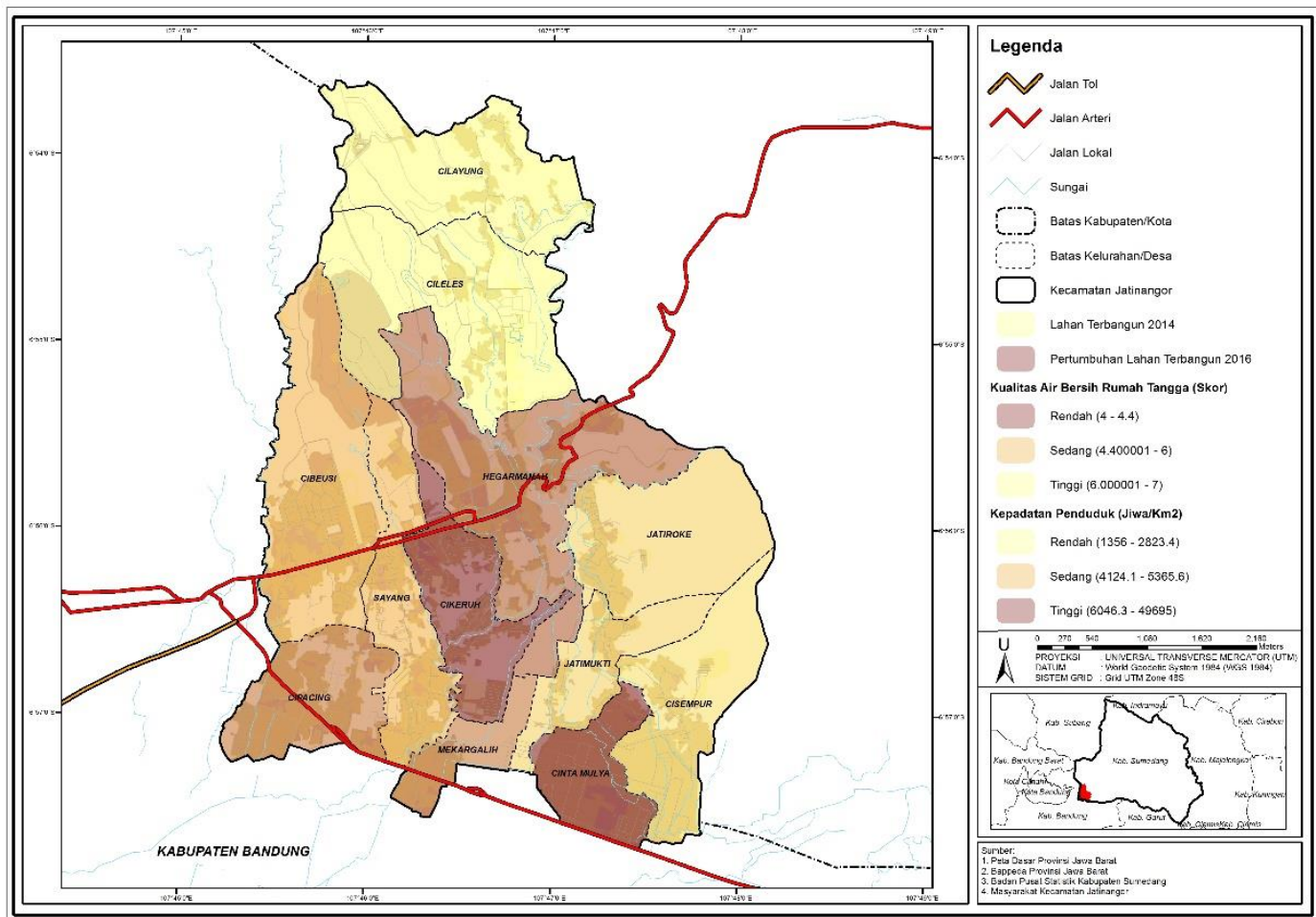

Gambar 8. Peta Overlay Pengaruh Pertumbuhan Penduduk dan Guna Lahan terhadap Kualitas Air Bersih Rumah Tangga

Berdasarkan peta tersebut, proses overlay dilakukan terhadap 3 (tiga) lapisan data yakni: kepadatan penduduk tahun 2016, pertumbuhan lahan terbangun 2014-2016, dan skor per kelurahan/desa terkait kualitas air bersih rumah tangga. Dapat dilihat pada peta tersebut, warna gelap yang nantinya akan menjadi hasil overlay pengaruh pertumbuhan penduduk dan guna lahan terhadap kualitas air bersih rumah tangga (lihat Gambar 8).

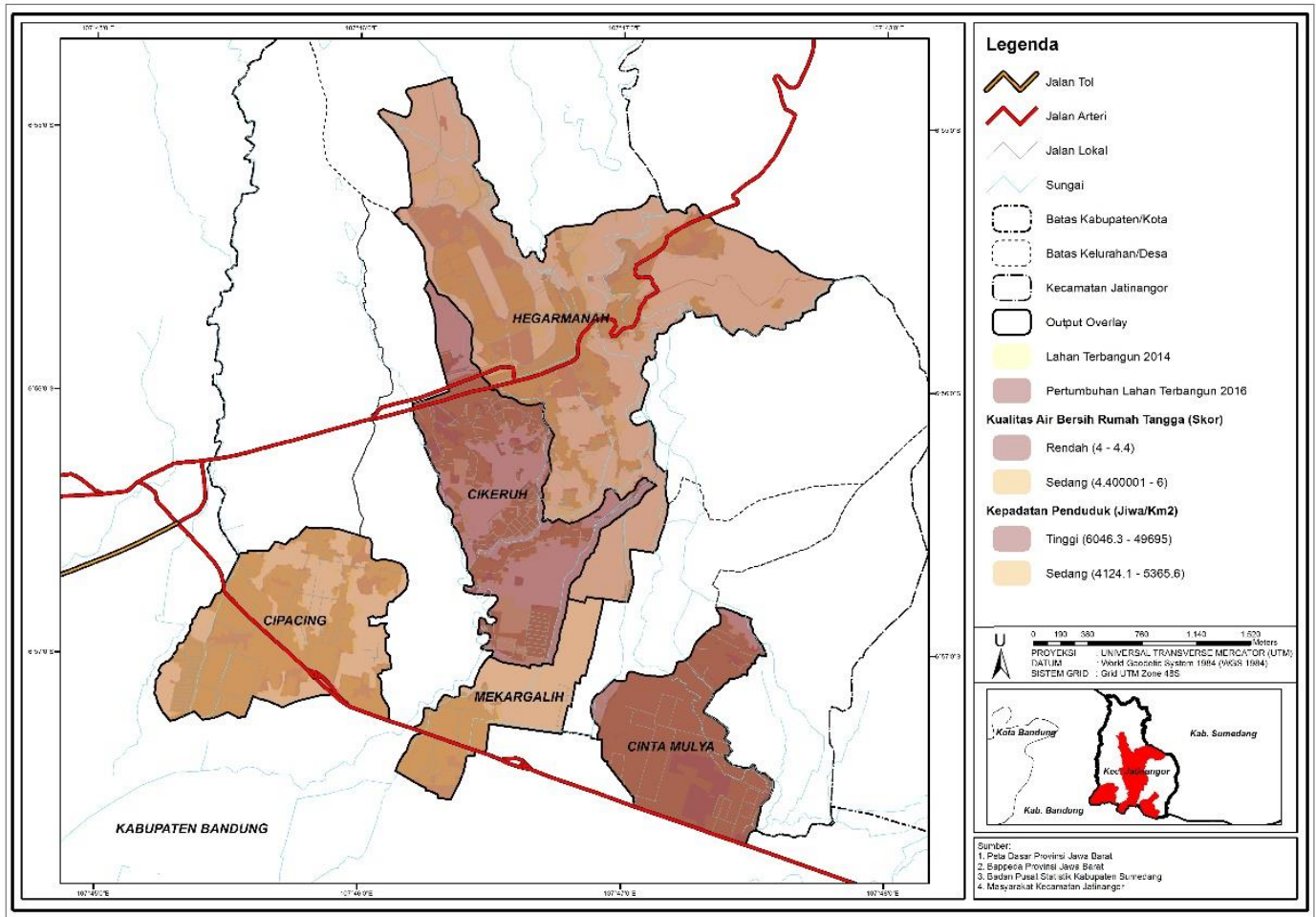

Gambar 9. Peta Output Overlay Pengaruh Pertumbuhan Penduduk dan Guna Lahan terhadap Kualitas Air Bersih Rumah Tangga 
Berdasarkan peta tersebut, melalui proses overlay Sistem Informasi Geografis (SIG) menghasilkan daerah-daerah output overlay pengaruh pertumbuhan penduduk dan guna lahan terhadap kualitas air bersih rumah tangga. Daerahdaerah output overlay tersebut berupa daerah dengan batas administrasi kelurahan/desa yakni di antaranya: Kelurahan/Desa Hegarmanah, Cikeruh, Cipacing, Mekargalih, dan Cinta Mulya dapat dilihat pada Gambar 9.

\section{Tabel 14. Kelurahan/Desa Hasil Output Overlay Pengaruh Pertumbuhan Penduduk dan Guna Lahan terhadap Kualitas Air Bersih Rumah Tangga}

\begin{tabular}{ccccc}
\hline No. & Kelurahan/Desa & \multicolumn{3}{c}{ Kategori } \\
\cline { 3 - 5 } & $\begin{array}{c}\text { Kepadatan Penduduk } \\
(\text { jiwa/km²) }\end{array}$ & $\begin{array}{c}\text { Pertumbuhan Lahan Terbangun } \\
\text { (ha) }\end{array}$ & $\begin{array}{c}\text { Kualitas Air Bersih Rumah } \\
\text { Tangga }\end{array}$ \\
\hline 1. & Hegarmanah & Sedang & 809,8 (Tinggi) & Rendah \\
2. & Cikeruh & Tinggi & 638,7 (Rendah) & Rendah \\
3. & Cipacing & Tinggi & 641,6 (Rendah) & Sedang \\
4. & Mekargalih & Tinggi & 601,2 (Rendah) & Sedang \\
5. & Cinta Mulya & Tinggi & 738,4 (Tinggi) & Rendah \\
\hline
\end{tabular}

Berdasarkan tabel tersebut, dapat diketahui terdapat 5 (lima) kelurahan/desa hasil output overlay pengaruh pertumbuhan penduduk dan guna lahan terhadap kualitas air bersih rumah tangga. Kelurahan/desa tersebut memiliki: kepadatan penduduk dengan kategori sedang dan tinggi; pertumbuhan lahan terbangun dengan kategori rendah dan tinggi; serta kualitas air bersih rumah tangga dengan kategori rendah dan sedang (lihat Tabel 14).

Tabel 15. Kategori Pengaruh Pertumbuhan Penduduk dan Guna Lahan terhadap Kualitas Air Bersih Rumah Tangga

\begin{tabular}{ccccc}
\hline Kategori & Kepadatan Penduduk & Pertumbuhan Lahan Terbangun & $\begin{array}{c}\text { Kualitas Air Bersih Rumah } \\
\text { Tangga }\end{array}$ & Kelurahan/Desa \\
\hline 1 & Sedang & Tinggi & Rendah & Hegarmanah \\
2 & Tinggi & Rendah & Rendah & Cikeruh \\
3 & Tinggi & Rendah & Sedang & Cipacing, Mekargalih \\
4 & Tinggi & Tinggi & Rendah & Cinta Mulya \\
\hline
\end{tabular}

Berdasarkan tabel tersebut, dapat diketahui terdapat 4 (empat) kategori pengaruh pertumbuhan penduduk dan guna lahan terhadap kualitas air bersih rumah tangga. Cinta Mulya (kategori 4) menjadi kelurahan/desa dengan keadaan yang paling terpuruk dikarenakan memilki kepadatan penduduk tinggi, pertumbuhan lahan terbangun tinggi, dan kualitas air bersih rumah tangga rendah (lihat Tabel 15). Hasil tersebut menunjukkan bahwa pertumbuhan penduduk dan guna lahan berpengaruh terhadap kualitas air bersih rumah tangga.

\section{KESIMPULAN}

Kecamatan Jatinangor Kabupaten Sumedang diarahkan oleh Provinsi Jawa Barat sebagai Kawasan Strategis Provinsi (KSP) dengan prioritas pada bidang lingkungan hidup dan sosial. Jatinangor memiliki urgensi permasalahan lingkungan hidup dan sosial kependudukan. Penelitian ini membahas pengaruh pertumbuhan penduduk dan guna lahan terhadap kualitas air bersih rumah tangga di Jatinangor. Kondisi pertumbuhan dan kepadatan penduduk pada Kecamatan Jatinangor mengalami peningkatan, hal tersebut berdampak pada konversi lahan menjadi terbangun. Peningkatan jumlah lahan terbangun menyebabkan aktivitas di lahan terbangun tersebut meningkat, hal itu menjadikan kebutuhan air bersih sebagai kebutuhan yang vital bagi penduduk menjadi meningkat pula.

Kecamatan Jatinangor memiliki kondisi sumber air tanah yang mengalami penurunan kedudukan muka air dan pencemaran air, serta kondisi debit sumber air PDAM pun juga mengalami penurunan. Pada kaitannya dengan pengelolaan air bersih, masyarakat Jatinangor kurang berpartisipasi dalam pengelolaan lingkungan air bersih. Sementara itu, jangkauan pelayanan air PDAM pun masih sangat kurang. Lebih lanjut, kualitas air bersih rumah tangga berdasarkan persepsi masyarakat Jatinangor memiliki hasil yakni kualitas air kurang memadai untuk kebutuhan seharihari.

Pada proses spatial overlay, kelurahan/desa dengan kepadatan penduduk yang tinggi memiliki pertumbuhan lahan terbangun dengan kategori rendah dan tinggi, sedangkan kualitas air bersih rumah tangga dengan kategori sedang dan rendah. Kelurahan/desa dengan kepadatan penduduk yang sedang memiliki pertumbuhan lahan terbangun dengan 
kategori tinggi, sedangkan kualitas air bersih rumah tangga dengan kategori rendah. Guna lahan pada kelurahan/desa hasil output spatial overlay didominasi oleh lahan terbangun industri tekstil yang terdapat pada Kelurahan/Desa Cipacing, Mekargalih, dan Cinta Mulya. Sementara itu, guna lahan lainnya yakni; perdagangan jasa, apartemen/hotel/kost, perumahan/permukiman dan instansi pendidikan tinggi terdapat pada Kelurahan/Desa Cikeruh dan Hegarmanah. Konversi lahan terbangun tersebut menyebabkan aktivitas di dalamnya meningkat dan berdampak pada pemenuhan kebutuhan air bersih yang meningkat pula.

Berdasarkan perihal tersebut, pertumbuhan penduduk dan pembangunan fisik yang pesat sehingga konversi lahan sangat tinggi di Jatinangor berpengaruh terhadap kualitas air bersih rumah tangga.

\section{DAFTAR PUSTAKA}

Amirin, T.M. (2011). Populasi dan Sampel Penelitian 4: Ukuran Sampel Rumus Slovin. Diakses dari https://tatangmanguny.wordpress.com/2010/04/19/ukuran-sampel-rumus-slovin/

Badan Geologi Pusat Air Tanah dan Geologi Tata Lingkungan Kementerian Energi dan Sumber Daya Mineral. (2011). Kedudukan Muka Air Tanah Kecamatan Jatinangor Tahun 2000-2011

Badan Pusat Statistika. (n.d.). Laju Pertumbuhan Penduduk-Badan Pusat Statistik. Diakses dari https://sirusa.bps.go.id/index.php?r=indikator/view\&id=86.

Badan Pusat Statistik Kabupaten Sumedang (2016). Kecamatan Jatinangor dalam Angka Tahun 2016. Diakses dari: https://sumedangkab.bps.go.id/publication/2016/09/26/bc48a8ac3b7d963efe59345e/kecamatan-jatinangor-dalam-angka2016.html

Badan Pusat Statistik Kabupaten Sumedang (2017). Kabupaten Sumedang dalam Angka Tahun 2017. Diakses dari https://sumedangkab.bps.go.id/publication/2017/08/11/fofd794d8cc1e4eb1c473c01/kabupaten-sumedang-dalam-angka2017.html

Bappeda Provinsi Jawa Barat. (2017). Data Luasan Penggunaan Lahan Kecamatan Jatinangor Tahun 2014-2016.

Bappeda Provinsi Jawa Barat. (2017). Data Penggolongan Luasan Penggunaan Lahan Non Terbangun dan Lahan Terbangun Kecamatan Jatinangor Tahun 2014-2016

Bappeda Provinsi Jawa Barat. (2017). Peta Pertumbuhan Lahan Terbangun Kecamatan Jatinangor Tahun 2014-2016

European, U. (2008). Sustainable Water Management. European Union, 1.

Fritsche, U. R., Epler, U., Iriarte, L., Laaks, S., \& Kap, T. (2015). Resource-Efficient Land Use - Towards a Global Sustainable Land Use Standard (GLOBALANDS). Environmental Study of the Federal Ministry for the Environment, Nature Conservation, Building, and Nuclear Safety/Project No. (FKZ) 371193 101, 22.

Handayani, D., Soelistijadi, R., \& Sunardi. (2005). Pemanfaatan Analisis Spasial untuk Pengolahan Data Spasial Sistem Informasi Geografi. Jurnal Teknologi Informasi DINAMIK, X(2), 108. Diakses dari https://www.researchgate.net/publication/277175313_Pemanfaatan_Analisis_Spasial_untuk_Pengolahan_Data_Spasial_S istem_Informasi_Geografi

Howard, G., \& Bartram, J. (2003). Domestic Water Quantity, Service Level and Health. WHO/SDE/WSH/03.02, 2.

Kodoatie, R. J., \& Roestam Sjarief. (2010). Tata Ruang Air. Yogyakarta: ANDI.

Mirsa, R. (2011). Elemen Tata Ruang Kota. Yogyakarta: Graha Ilmu.

Pasaribu, R. B. (2013). Pengumpulan Data Sekunder. Diakses dari https://rowlandpasaribu.files.wordpress.com/2013/03/07pengumpulan-data-sekunder1.pdf

PDAM Kab. Sumedang. (2017). Data Debit Sumber Air PDAM Kecamatan Jatinangor Tahun 2011-2016.

PDAM Kab. Sumedang. (2017). Data Pengguna Air PDAM dan Air Tanah Kecamatan Jatinangor Tahun 2011-2016.

PDAM Kab. Sumedang. (2017). Data Perbandingan Jumlah KK dengan Pengguna Air PDAM dan Pengguna Air Tanah Kecamatan Jatinangor Tahun 2011-2016.

Peraturan Daerah Nomor 2 Tahun 2012 Tentang Rencana Tata Ruang Wilayah Kabupaten Sumedang Tahun 2011-2031

Peraturan Daerah Provinsi Jawa Barat Nomor 22 Tahun 2010 Tentang Rencana Tata Ruang Wilayah Provinsi Jawa Barat Tahun 2009-2029

Ritohardoyo, S. (2013). Penggunaan dan Tata Guna Lahan. Yogyakarta: Penerbit Ombak.

Rukmana, N., Steinberg, F., \& Robert van der Hoff. (1993). Manajemen Pembangunan Prasarana Perkotaan. Jakarta: Pustaka LP3ES.

Setiawati, F. A., Djemari Mardapi, \& Saifuddin Azwar. (2013). Penskalaan Teori Klasik Instrumen Multiple Intelligences Tipe Thurstone dan Likert. Jurnal Penelitian dan Evaluasi Pendidikan, 17(2).

Setyorini, B. (2012). Analisis Kepadatan Penduduk dan Proyeksi Kebutuhan Permukiman Kecamatan Depok Kabupaten Sleman Tahun 2010-2015. Jurnal Universitas Muhammadiyah Surakarta, 2.

Silalahi, U. (2010). Metode Penelitian Sosial. Bandung: PT. Refika Aditama.

SNI 03-1733-2004 tentang Tatacara Perencanaan Lingkungan Permukiman di Perkotaan

Subagyo, P. (2003). Statistik Deskriptif: Edisi 4. Yogyakarta: BPFE-Yogyakarta. 
Sugiyono. (2009). Metode Penelitian Kuantitatif Kualitatif dan R\&D. Bandung: Alfabeta.

Suryabrata, S. (2006). Metodologi Penelitian. Jakarta: PT. RajaGrafindo Persada.

Suwartono. (2014). Dasar-Dasar Metodologi Penelitian. Yogyakarta: ANDI.

Yunus, \& Hadi Sabari. (2005). Manajemen Kota: Perspektif Spasial. Yogyakarta: Pustaka Pelajar Offset.

Yuri, T., \& Nurcahyo, R. (2013). TQM: Manajemen Kualitas Total dalam Perspektif Teknik Industri. Jakarta: PT. Indeks. 